\title{
Impact of Organic Manures and Biofertilizers on available NPK in Soil and Nutrient Composition of Okra Fruit
}

\author{
N. Akhila*, D. Anitha Kumari, M. Hanuman Nayak and D. Vijaya \\ Sri Konda Laxman Telangana State Horticultural University, College of Horticulture, \\ Rajendranagar, Hyderabad, Telangana 500030, India \\ *Corresponding author
}

A B S T R A C T

\section{Keywords}

FYM, Neem cake, Poultry manure, Vermicompost, Arka Microbial Consortium

Article Info

Accepted:

07 April 2019

Available Online:

10 May 2019

\begin{abstract}
An experiment was carried out on sandy loam soil to evaluate the impact of organic manures (farmyard manure, vermicompost, poultry manure and neem cake) and bio fertilizers (Arka Microbial Consortium) on available NPK in soil and nutrient composition of okra fruit during kharif season of 2017- 2018 at vegetable research station, Sri Konda Laxman Telangana State Horticultural University, Rajendranagar, Hyderabad. In organic farming the use of mineral fertilizers is highly restricted; so, for present experimentation virgin soils were selected. Ten treatments were tried out in randomized block design with three replications. Soil chemical parameters viz., available $\mathrm{N}, \mathrm{P}_{2} \mathrm{O}_{5}$ and $\mathrm{N}$ per cent, $\mathrm{P}$ per cent in okra fruit were found to be affected significantly due to T10 with FYM $\left(5 \mathrm{t} \mathrm{ha}^{-1}\right)+$ VC $\left(1.25 \mathrm{~kg} \mathrm{ha}^{-1}\right)+\mathrm{NC}\left(125 \mathrm{~kg} \mathrm{ha}^{-1}\right)+\mathrm{PM}\left(1.25 \mathrm{~kg} \mathrm{ha}^{-1}\right)+\mathrm{AMC}\left(12.5 \mathrm{~kg} \mathrm{ha}^{-1}\right)$. We conclude that chemical fertilizers have adverse effect on soil health and environment, so it is not advisable to use. Organic manures and biofertilizers can activate the microbial and enzymatic activity of the soil thus increases the soil physico-chemical properties, residual nutrients concentration and also nutrient composition of okra fruit.
\end{abstract}

\section{Introduction}

Okra [Abelmoschus esculentus (L.) Moench] is an important annual vegetable crop grown in tropical and sub-tropical parts of the world mainly for its tender green fruits used as vegetable. It is rich in vitamins, calcium, potassium and other minerals. Besides, being a short duration hardy vegetable crop, it is also known for its nutritional and medicinal importance. It is said to be very useful against genito-urinary disorders, spermatorrhoea and chronic dysentery (Nadkarni, 1972). India is the largest producer of okra in the world. At present, okra cultivated at an extent of 5.11 lakh ha across the country and with an estimated production of $58.48 \mathrm{MT}$ and with a productivity of $11.4 \mathrm{MT} \mathrm{ha}^{-1}$ (NHB 2016). In Telangana the okra occupies an area of 12.78 thousand ha and with the production of 171.69 MT. The major okra growing states are Uttar Pradesh, Bihar and West Bengal. Despite of its nutritional richness, it has not yet attained the optimum yields because of a 
continuous decline in the fertility of soil which could be attributed to imbalanced use of fertilizers in our country. Among nutrients required for adequate nutrition and high yield of okra, nitrogen $(\mathrm{N})$ is the most critical. It has its main role in contributing to the plant growth characters thereby influencing the yield and quality parameters which are generally directly correlated to each other. Unfortunately, N deficiency is widespread in India on account of low available soil $\mathrm{N}$ and organic matter content as a result of nitrification and leaching losses. Imbalanced application of urea for obtaining higher yields has reduced the fertility of the soil. Phosphorus fertilization can influence fruiting and fruit development of okra. Phosphorus is called the "Key to life" because it is directly involved in most living process. It is a key constituent of ATP has significant role in energy transformation in plants and also in various physiological processes. Phosphorus helps in nutrients uptake by promoting root growth and thereby ensuring a good pod yield through the increase in total dry matter. Potassium plays a unique role in osmotic regulation, opening and closing of stomata and improves the colour, flavors and size of fruits. So, there is an importance of availability of nutrients in the soil for proper growth of the plant. The green revolution has popularized the use of chemical fertilizers to achieve higher productivity. Excessive use of chemical fertilizers to obtain high yield resulted in several hazards to the soil, deficiency of micronutrients (Kanwar and Randhawa, 1978) and nutrient imbalance ultimately resulting in the reduction of crop yield. The chemical use is hitting the sustainability in soil and decreasing its potency. Therefore, farmers are in need of searching alternative to replace the chemical fertilizers. Organic farming can maintain soil quality. In recent days, the use of organic inputs is becoming popular in the world wide. Organic manures viz., FYM, vermicompost
(VC), poultry manure (PM) and neem cake help in the improvement of soil structure, aeration and water holding capacity of soil. Further, it stimulates the activity of microorganisms that makes the plant to get the macro and micro-nutrients through enhanced biological processes, increase nutrient solubility, alter soil salinity, sodicity and $\mathrm{pH}$.

\section{Materials and Methods}

A field experiment entitled 'impact of organic manures and bio-fertilizers on available NPK in soil and nutrient composition of okra fruit comprising of 10 treatment combinations viz., organic manures (FYM, Poultry Manure, Neem Cake and Vermicompost) and biofertilizers (Arka Microbial Consortium)in randomized block design during kharif season of 2017- 2018 at vegetable research station, Sri Konda Laxman Telangana State Horticultural University, Rajendranagar, Hyderabad.

\section{Soil analysis}

\section{Soil sampling}

The soil samples from each of the treatments, each weighing $1.0 \mathrm{~kg}$ were collected by adopting standard soil sampling procedures. The samples were dried under shade. They were then pounded and sieved using $2 \mathrm{~mm}$ sieve. The sieved soil samples were used for the analysis. The soil samples were analysed as per the standard procedures. Soil samples from each treatment plot were collected at 0 $30 \mathrm{~cm}$ depth at the end of the experimental period. The samples were analysed for available Nitrogen, Phosphorous and Potassium.

\section{Available nitrogen}

The available nitrogen was determined using alkaline potassium permanganate method 
(Subbaiah and Asija, 1956) by digestion, distillation and collection of $\mathrm{NH}_{3}$ in 2 per cent boric acid and then titrating it against standard sulphuric acid.

\section{Available phosphorus}

Available phosphorus in the soil was extracted with the help of Bray'sNo. 1 Extract $(0.03 \mathrm{~N}$ Ammonium fluoride $=0.025 \mathrm{Hcl})$. Further, phosphorus in the filtrated extract was determined by chlorostamers reduced molybdophosphate blue colour method (Jackson, 1967). The intensity of colour read was at wave length.

\section{Available potassium}

The available potash in the soil was determined by flame photo meter methods as suggested by Jackson (1967).

\section{Nutrient composition of okra}

Macronutrients in okra: (NPK per cent in Dry matter)

\section{Chemical analysis of fruit samples}

It was done by adopting standard conventional procedures.

\section{Collection of fruit sample}

Fruits from all treatments and replications were collected in separate paper bags for analysis.

\section{Washing and drying}

The collected fruits were initially washed with tap water and then with 0.2 per cent detergent, $0.1 \mathrm{~N} \mathrm{HCl}$ to remove the dust and again washed with distilled and double distilled water, they were wiped with blotting paper and air dried for 2 days. Later they are oven dried at $60^{\circ} \mathrm{C}$ for 48 hours to a constant weight. The dried material is grounded into fine powder in an electric stainless steel mill using $0.5 \mathrm{~mm}$ sieve. The powdered samples were analysed for NPK following the standard procedures.

\section{Estimation of nitrogen (per cent)}

Nitrogen in plant samples was determined by employing KELPLUS digestion and distillation systems. Plant material of $0.1 \mathrm{~g}$ was digested with conc. $\mathrm{H}_{2} \mathrm{SO}_{4}$ and $\mathrm{H}_{2} \mathrm{O}_{2}$. After digestion, the resultant clear liquid was transferred into distillation tube and distilled with $10 \mathrm{ml}$ of 40 per cent Sodium hydroxide. Thus, $\mathrm{NH}_{3}$ liberated was absorbed in 4 per cent Boric acid. The absorbed NH3 was titrated with $0.1 \mathrm{~N} \mathrm{H}_{2} \mathrm{SO}_{4}$ in the presence of mixed indicator (Subbaiah and Asija, 1956).

\section{Di acid digestion}

One gram of dried and powdered plant material was digested in 10mlof di acid mixture of Nitric acid $\left(\mathrm{HNO}_{3}\right)$ and Perchloric acid $\left(\mathrm{HclO}_{4}\right)$ in 9:4proportion. The extract was finally made up to $100 \mathrm{ml}$ with distilled water and filtered through Whatmann No.1 filter paper. This solution can be used for the estimation of following elements.

\section{Estimation of phosphorus (per cent)}

Phosphorous in the plant material was determined by Vanado-molybdo phosphoric yellow colour method. $10 \mathrm{ml}$ of solution (after digestion) was taken in to $50 \mathrm{ml}$ volumetric flask; to it $10 \mathrm{ml}$ of Barton's reagent was added, and the volume was made up to the mark. After 10 minutes the transmittance was determined by feeding to spectrophotometer at $420 \mathrm{~nm}$. Later from the ppm obtained from standard curves the percentage of $\mathrm{P}$ in the plant sample was determined by using standard curve (Jackson, 1967). 


\section{Estimation of potassium (per cent)}

Potassium was determined by direct feeding of the extract to the Flame Photometer after adjusting the instrument with suitable potassium standards (Tandon, 1993).

\section{Results and Discussion}

Available nitrogen $\left(\mathrm{kg} \mathrm{ha}^{-1}\right)$ and phosphorus $\left(\mathrm{kg} \mathrm{ha}^{-1}\right)$ in soil

The highest post-harvest available soil nitrogen $\left(336.6 \mathrm{~kg} \mathrm{ha}^{-1}\right)$ and the highest postharvest available soil phosphorus (39.5 kg ha $\left.{ }^{1}\right)$ was recorded in T10 with Farm yard manure $\left(5 \mathrm{tha}^{-1}\right)+$ Vermicompost $(1.25 \mathrm{~kg}$ $\left.\mathrm{ha}^{-1}\right)+$ Neem cake $\left(125 \mathrm{~kg} \mathrm{ha}^{-1}\right)+$ Poultry manure $\left(1.25 \mathrm{~kg} \mathrm{ha}^{-1}\right)+$ Arka microbial consortium $\left(12.5 \mathrm{~kg} \mathrm{ha}^{-1}\right)$. The buildup of available $\mathrm{P}$ in the soil could be due to the organic acids which were released during the microbial decomposition of vermicompost increasing the available $\mathrm{P}$ in soil (Khan et al., 1974) (Table 1).

\section{Available potassium $\left(\mathrm{kg} \mathrm{ha}^{-1}\right)$ in soil}

There was no significant difference found among various treatments of organic manures like FYM, vermicompost, neem cake, poultry manure and bio- fertilizers with respect to post-harvest available soil potassium. The results are presented in Table 2. However, the highest post-harvest available soil potassium $\left(530 \mathrm{~kg} \mathrm{ha}^{-1}\right)$ was recorded in T10 with Farm yard manure $\left(5 \mathrm{t} \mathrm{ha}^{-1}\right)+$ Vermicompost $(1.25$ $\left.\mathrm{kg} \mathrm{ha}^{-1}\right)+$ Neem cake $\left(125 \mathrm{~kg} \mathrm{ha}^{-1}\right)+$ Poultry manure $\left(1.25 \mathrm{~kg} \mathrm{ha}^{-1}\right)+$ Arka microbial consortium $\left(12.5 \mathrm{~kg} \mathrm{ha}^{-1}\right)$. The higher buildup of available $\mathrm{K}$ in soil due to the reduction of $\mathrm{K}$ fixation, release of $\mathrm{K}$ due to the interaction of organic matter with clay, and direct addition of $\mathrm{K}$ to the available pool of soil. The organic manures positively influenced the available NPK contents of soil after the crop harvest. The increase in available NPK may be due to added supply of nutrients and proliferous root system developed under balanced nutrient application resulting in better absorption of water and nutrient along with improved physical environment (Devender et al., 1998). The availability of nutrients can be attributed to the solubilizing effect of minerals by decomposing FYM (Subbaiah, 1982).

The increase in available NPK indicated that the NPK present in the manure was available to the crop and the application of FYM, vermicompost, poultry manure, neem cake and bio-fertilizers would have increased the available NPK content in soil. Similar results were obtained in chilli by Rajesh (1997) and Doikova (1979) in brinjal.

\section{Nutrient composition (\%) of okra fruit}

\section{Nitrogen $(\%)$}

Among the different organic manures and bio-fertilizers treatments, the maximum $\mathrm{N}$ content of fruit T10 (2.61 per cent) was recorded in plants treated with Farm yard manure $\left(5 \mathrm{t} \mathrm{ha}^{-1}\right)+$ Vermicompost $(1.25 \mathrm{~kg}$ $\left.\mathrm{ha}^{-1}\right)+$ Neem cake $\left(125 \mathrm{~kg} \mathrm{ha}^{-1}\right)+$ Poultry manure $\left(1.25 \mathrm{~kg} \mathrm{ha}^{-1}\right)+$ Arka microbial consortium $\left(12.5 \mathrm{~kg} \mathrm{ha}^{-1}\right)$. The increased $\mathrm{N}$ uptake could be due to increased and prolonged availability of $\mathrm{N}$ to the plants in these treatments and also due to increased dry matter yield. Nutrient uptake is a positive function of dry matter yield (Ramakal et al., 1988). This is in consonance with the findings of Chalapathi et al., (1997) in stevia and Mallangouda et al., (1995) in onion and garlic.

\section{Phosphorus (\%)}

The highest $\mathrm{P}$ content in fruit T10 (0.49 per cent) was recorded in plants treated with Farm yard manure $\left(5 \mathrm{tha}^{-1}\right)+$ Vermicompost $(1.25$ $\left.\mathrm{kg} \mathrm{ha}^{-1}\right)+$ Neem cake $\left(125 \mathrm{~kg} \mathrm{ha}^{-1}\right)+$ Poultry 
manure $\left(1.25 \mathrm{~kg} \mathrm{ha}^{-1}\right)+$ Arka microbial consortium (12.5 $\left.\mathrm{kg} \quad \mathrm{ha}^{-1}\right)$. Normally phosphorus is said to be in fixed form and its absorption is a slow process or sometimes not available. Interestingly, in the present study plant supplied with the organic manures have recorded larger uptake of phosphorus.

This could be attributed to their chelating action in making ions available and maintaining soil physical condition. It could also be due to the increased availability of $\mathrm{P}$ due to the solubility effect of organic acids which were produced from the decomposing organic manures. Further FYM and vermicompost might also have reduced the fixation of $\mathrm{P}$ and increased the availability of $\mathrm{P}$ in soil solution for its better absorption resulting in increased uptake of $\mathrm{P}$ in okra. Neem cake contains 0.25 per cent of $P$ in addition to nitrogen. The additional phosphorus might be one of the reasons for improving the uptake of $\mathrm{P}$ by the plants. More over neem cake might have enriched the soil with additional phosphorus and improved the water retention capacity of the soil and thereby maintained a condusive environment in the soil for making phosphorus more available to the plants in higher quantities (Bringi, 1987).

\section{Potassium (\%)}

There was no significant difference found among various treatments of organic manures like FYM, vermicompost, neem cake, poultry manure and bio- fertilizers with respect to potassium percentage in fruit. The results are presented in Table 3. However, the highest potassium percentage in fruit T10 (1.86 per cent) was recorded in plants treated with Farm yard manure $\left(5 \mathrm{t} \mathrm{ha}^{-1}\right)+$ Vermicompost $(1.25$ $\left.\mathrm{kg} \mathrm{ha}^{-1}\right)+$ Neem cake $\left(125 \mathrm{~kg} \mathrm{ha}^{-1}\right)+$ Poultry manure $\left(1.25 \mathrm{~kg} \mathrm{ha}^{-1}\right)+$ Arka microbial consortium (12.5 kg ha ${ }^{-1}$ ). Nitrogen possibly might have influenced the potassium uptake by virtue of its complementary action with potassium. The increase in $\mathrm{K}$ uptake was due to the increased availability of nutrients from the native, as well as from the mineralized organic manures which might have increased the concentration of $\mathrm{K}$ in soil solution making it readily available for absorption. Similar trend was recorded in onion by Geetha (1994). Potash likely to be maintained in exchangeable form in soil treated with organic manures, which in turn might have restricted the $\mathrm{K}+$ ions getting fixed by inorganic clay particles in soil. The increased uptake of NPK due to addition of organic manure is due to the action of organic acids which form organic matter complex. Some of which in addition to influencing $\mathrm{PH}$, form stable complexes or chelated compounds with cations responsible for phosphate fixation (Prabhu et al., 2002). The application of FYM, vermicompost, poultry manure and neem cake, in combination with bio-fertilizers significantly increased yield, improved the chemical properties of the soil, increased the nutrient availability and thereby leads to increased nutrient uptake by okra (Fig. 1 and 2).

Table.1 Nutrient status of the soil before planting

\begin{tabular}{|c|c|}
\hline \multicolumn{2}{|c|}{ Initial soil status } \\
\hline $\mathbf{P}^{\mathbf{H}}$ & 8.25 \\
\hline $\mathbf{E C}$ & $0.69 \mathrm{~ms} \mathrm{~cm}^{-1}$ \\
\hline $\mathbf{N}$ & $188 \mathrm{~kg} \mathrm{ha}^{-1}$ \\
\hline $\mathbf{P}$ & $15 \mathrm{~kg} \mathrm{ha}^{-1}$ \\
\hline $\mathbf{K}$ & $433 \mathrm{~kg} \mathrm{ha}^{-1}$ \\
\hline
\end{tabular}


Table.2 Available NPK $\left(\mathrm{kg} \mathrm{ha}^{-1}\right)$ in the soil after harvest of okra as affected by different organic manures and biofertilizers

\begin{tabular}{|c|c|c|c|}
\hline Treatments & Nitrogen $(\mathrm{kg})$ & Phosphorus (kg) & Potassium (kg) \\
\hline T1: FYM (20 t ha' $\left.{ }^{-1}\right)$ & 281.1 & 32.7 & 498 \\
\hline T2: FYM $\left(20 \mathrm{t} \mathrm{ha}^{-1}\right)+\operatorname{AMC}\left(12.5 \mathrm{tha}^{-1}\right)$ & 294.1 & 36.1 & 499.1 \\
\hline T3: Vermicompost $\left(5 \mathrm{t} \mathbf{h a}^{-1}\right)$ & 299.4 & 37.8 & 499.2 \\
\hline T4: Vermicompost $\left(5 \mathrm{t} \mathrm{ha}^{-1}\right)+\mathrm{AMC}\left(12.5 \mathrm{t} \mathrm{ha} \mathrm{h}^{-1}\right)$ & 317.6 & 39.3 & 511.1 \\
\hline T5: Neem cake $\left(500 \mathrm{~kg} \mathrm{ha}^{-1}\right)$ & 254.4 & 31.4 & 492.1 \\
\hline T6: Neem cake $\left(500 \mathrm{~kg} \mathrm{ha}^{-1}\right)+$ AMC $\left(12.5 \mathrm{t} \mathrm{ha}^{-1}\right)$ & 277 & 31.6 & 497.1 \\
\hline T7: Poultry manure $\left(5 t \mathrm{ha}^{-1}\right)$ & 234.8 & 29.3 & 465.1 \\
\hline T8: Poultry manure $\left(5 \mathrm{t} \mathrm{ha}^{-1}\right)+\mathrm{AMC}\left(12.5 \mathrm{t} \mathrm{ha}^{-1}\right)$ & 241.9 & 31 & 466.6 \\
\hline $\begin{array}{l}\text { T9: FYM }\left(5 \mathrm{~h} \mathrm{ha}^{-1}\right)+\text { Vermicompost }(1.25 \mathrm{t} \mathrm{ha} \\
\left.\text { kg ha }^{-1}\right)+ \text { Neem cake }(125 \\
\left(1.25 \mathrm{tha}^{-1}\right)\end{array}$ & 324 & 39.4 & 511.2 \\
\hline $\begin{array}{l}\text { T10: FYM }\left(5 \mathrm{ha}^{-1}\right)+\text { Vermicompost }\left(1.25 \mathrm{t} \mathrm{ha}^{-1}\right)+\text { Neem cake } \\
\left(125 \mathrm{~kg} \mathrm{ha}^{-1}\right)+\text { Poultry manure }\left(1.25 \mathrm{tha}^{-1}\right)+\text { AMC }\left(12.5 \mathrm{tha}^{-1}\right)\end{array}$ & 336.6 & 39.5 & 530 \\
\hline S.Em \pm & 3.3 & 1 & 25.2 \\
\hline CD at $5 \%$ Level & 9.9 & 3.1 & NS \\
\hline
\end{tabular}

FYM = Farm yard manure

$\mathrm{AMC}=$ Arka microbial consortium

Table.3 Impact of different organic manures and bio-fertilizers on nutrientcomposition of okra fruit

\begin{tabular}{|c|c|c|c|}
\hline Treatments & Nitrogen $(\%)$ & Phosphorus (\%) & Potassium (\%) \\
\hline $\mathrm{T}_{1}:$ FYM $\left(20 \mathrm{t} \mathrm{ha}^{-1}\right)$ & 2.15 & 0.41 & 1.69 \\
\hline T2: FYM $\left(20 \mathrm{t} \mathrm{ha}^{-1}\right)+\mathrm{AMC}\left(12.5 \mathrm{t} \mathrm{ha}{ }^{-1}\right)$ & 2.16 & 0.43 & 1.71 \\
\hline T3: Vermicompost $\left(5 \mathrm{t} \mathrm{ha}{ }^{-1}\right)$ & 2.2 & 0.45 & 1.8 \\
\hline T4: Vermicompost $\left(5 \mathrm{t} \mathrm{ha}{ }^{-1}\right)+$ AMC (12.5t ha $\left.{ }^{-1}\right)$ & 2.3 & 0.46 & 1.81 \\
\hline T5: Neem cake (500 kg ha-1) & 2 & 0.39 & 1.62 \\
\hline T6: Neem cake $\left(500 \mathrm{~kg} \mathrm{ha}^{-1}\right)+$ AMC $\left(12.5 \mathrm{t} \mathrm{ha}^{-1}\right)$ & 2.13 & 0.4 & 1.63 \\
\hline T7: Poultry manure $\left(5 \mathrm{t} \mathrm{ha}^{-1}\right)$ & 1.5 & 0.37 & 1.55 \\
\hline T8: Poultry manure $\left(5 \mathrm{t} \mathrm{ha}{ }^{-1}\right)+\operatorname{AMC}\left(12.5 \mathrm{ha}^{-1}\right)$ & 1.96 & 0.38 & 1.6 \\
\hline $\begin{array}{l}\text { T9: FYM }\left(5 \mathrm{ha}^{-1}\right)+\text { Vermicompost }\left(1.25 \mathrm{t} \mathrm{ha}^{-1}\right)+ \\
\text { Neem cake }\left(125 \mathrm{~kg} \mathrm{ha}^{-1}\right)+\text { Poultry manure } \\
\left(1.25 \mathrm{tha}^{-1}\right)\end{array}$ & 2.4 & 0.48 & 1.82 \\
\hline $\begin{array}{l}\text { T10: FYM }\left(5 \mathrm{ha}^{-1}\right)+\text { Vermicompost }(1.25 \mathrm{t} \mathrm{ha} \\
\text { cake }\left(125 \mathrm{~kg} \mathrm{ha}^{-1}\right)+\text { Poultry manure }\left(1.25 \mathrm{tha}^{-1}\right)+\text { AMC } \\
\left(12.5 \mathrm{t} \mathrm{ha} \mathbf{~}^{-1}\right)\end{array}$ & 2.6 & 0.49 & 1.86 \\
\hline S.Em \pm & 0.17 & 0.01 & 0.113 \\
\hline CD at $5 \%$ Level & 0.51 & 0.03 & N.S \\
\hline
\end{tabular}

FYM = Farm yard manure

$\mathrm{AMC}=$ Arka microbial consortium 
Fig.1 Effect of organic manures and bio-fertilizers on Available $\mathrm{N}\left(\mathrm{kg} \mathrm{ha}^{-1}\right)$ and Available P in soil $\left(\mathrm{kg} \mathrm{ha}^{-1}\right)$

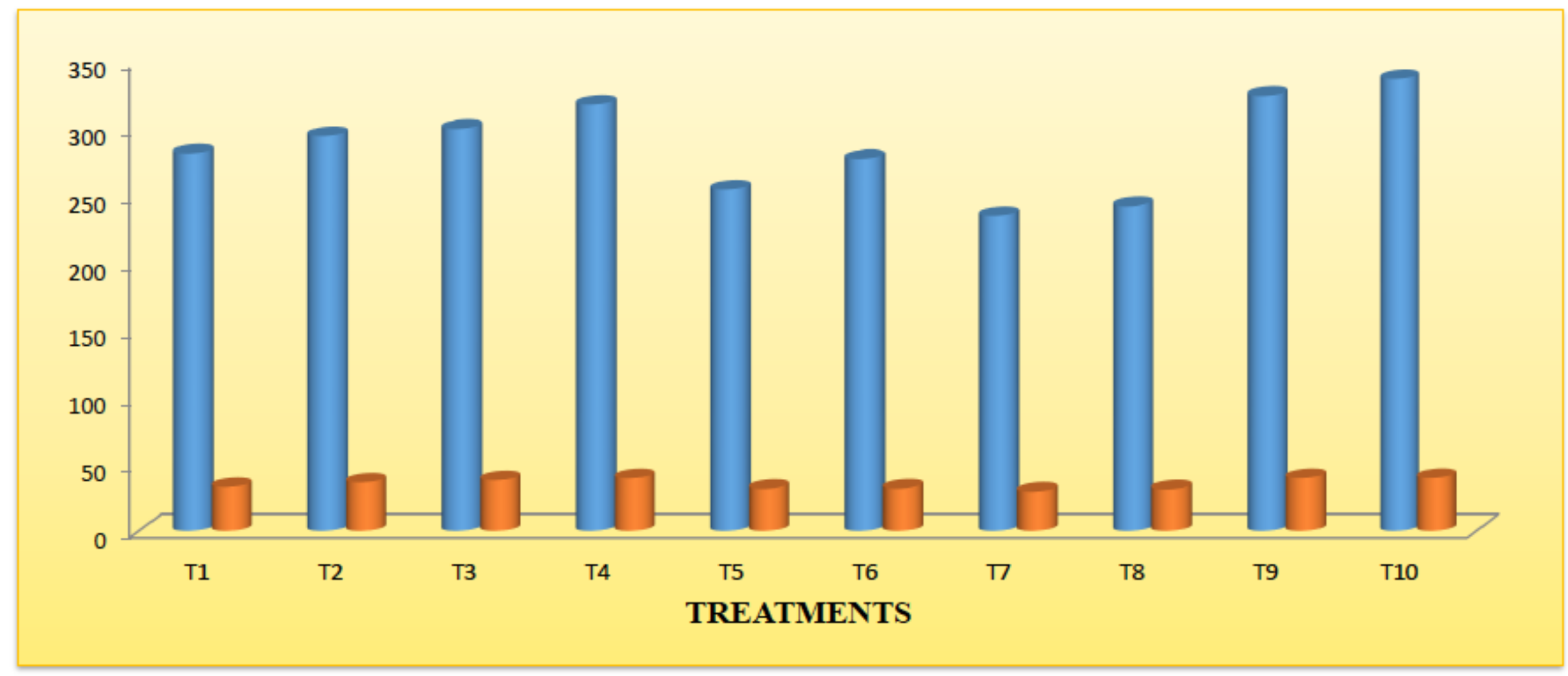

미 $\mathrm{N}\left(\mathrm{Kg} \mathrm{ha}^{-1}\right)$ 므 $\left.\mathrm{Pg} \mathrm{ha}{ }^{-1}\right)$

T1: FYM, T2: FYM + AMC, T3: Vermicompost, T4: Vermicompost + AMC, T5: Neem cake, T6: Neem cake + AMC T7: Poultry manure, T8: Poultry manure + AMC, T9: FYM + Vermicompost + Neem cake + Poultry manure,

T10: FYM + Vermicompost + Neem cake + Poultry manure + AMC

$\mathrm{AMC}=$ Arka Microbial Consortium, FYM= Farm Yard Manure 
Fig.2 Effect of organic manures and bio-fertilizers on nutrient composition of okra

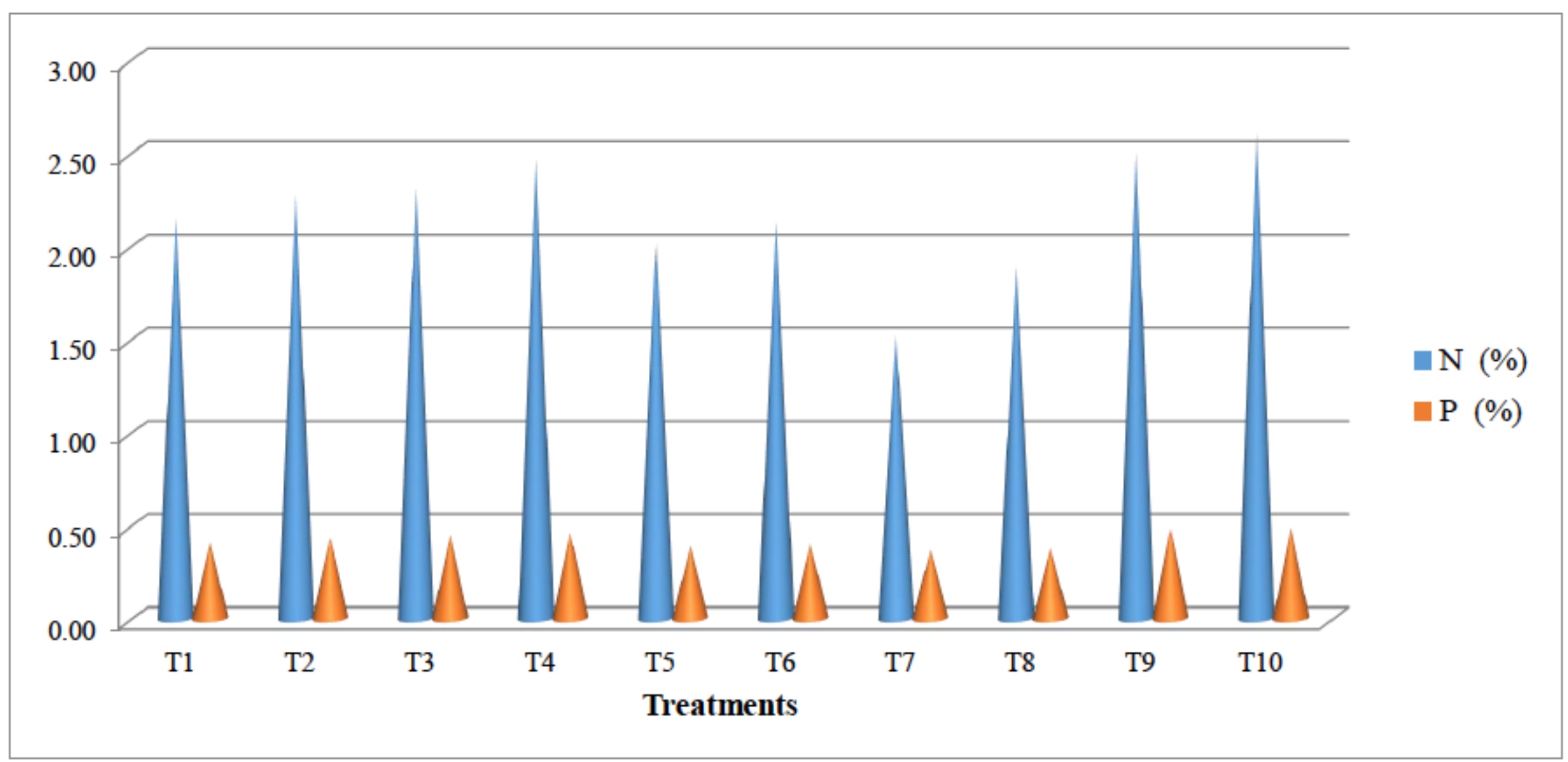

T1: FYM, T2: FYM + AMC, T3: Vermicompost, T4: Vermicompost + AMC, T5: Neem cake, T6: Neem cake + AMC, T7: Poultry manure, T8: Poultry manure + AMC, T9: FYM + Vermicompost + Neem cake + Poultry manure,

T10: FYM + Vermicompost + Neem cake + Poultry manure + AMC

$\mathrm{AMC}=$ Arka Microbial Consortium, FYM= Farm Yard Manure 
From the present study, it can be concluded that good soil conditions, available NPK in soil and nutrients in okra fruits are maintained by use of organic manures and bio fertilizers. Use of chemical fertilizers at higher amount possesses negative impact on the soil as well as on the environment. So, it is not advisable to use chemical fertilizers. Therefore, treatment $\mathrm{T} 10$ was found best considering the above points and recommended for okra cultivation under field condition.

\section{References}

Bringi, N. V. 1987. Nontraditional oilseeds in India. Oxford and IBH Publishing Company private Limited, New Delhi, pp 254.

Chalapathi, M. V., Shivaraj, B. and Parama, V.R.R. 1997. Nutrient uptake and yield of stevia (Stevia rebaudiana Bertoni.) as influenced by methods of planting and fertilizer levels. Crop Research. 14(2): 205-208.

Devender, K., Parmar, Pritam, K., Sharma. and Sharma, T.R. 1998. Integrated nutrient supply system for DPP 68 vegetable pea (Pisum sativum var. arvense) in dry temperate zone of Himachal Pradesh. Indian Journal of Agricultural Sciences. 68(2): 84-86.

Doikova, M. 1979. Nutrient uptake by eggplants. Fiziologiyana Rastemiyata. 5(3): 72-77.

Geetha, K. 1994. Effect of integrated use of farm yard manure and potassium fertilizer on potassium nutrition and yield of onion (Allium cepa L.) in Alfisol. M.Sc. (Ag) Thesis submitted to Andhra Pradesh Agricultural University, Hyderabad.

Jackson, M. L. 1967. Soil Chemical Analysis. Prefice Hall (India) Pvt Ltd. New Delhi.

Kanwar, J. S. and Randhawa, N. S. 1978. Micronutrient research in soil and plants in India, Technical Bulletein 50, Indian
Council of Agricultural Research, New Delhi.

Khan, M. W., Khan, A. M. and Saxena, S. K. 1974. Rhizosphere fungi nematodes of eggplant as influenced by oil cake amendments. Indian Phyto Pathology. 27(4): 480-484.

Mallangouda, B., Sulikeri, G. S., Hulamani, N. C., Murthy, B. G. and Madalgeri, B. B. 1995. Effect of NPK and FYM on growth parameters of onion, garlic and coriander. Current Research. 24(11): 212-213.

Nadkarni, K. M. 1972. Indian Meteria and Medica. Nadkarni and Co., Bombay, India.

NHB 2016. Indian Horticulture Database, National Horticulture Board, Gurgaon, India. pp.18.

Prabhu, T., Narwadkar, P. R., Sajindranath, A. K. and Rathod, N. G. 2002. Integrated nutrient management in coriander. South Indian Horticulture. 50: 680-84.

Rajesh, S. 1997. Comparative performance of chillies Cv. PLR-1 with inorganic fertilizers and vermicompost in association with bio-fertilizers. Thesis submitted to Annamalai university, Annamalai nagar.

Ramakal, K. S., Khera, A. P., Bhatia, R. N., Gupta, S. P. and Duhan, B. S. 1988. Effect of combined application of FYM and inorganic fertilizers on grain yield and soil fertility status in Bajra wheat crop sequence. Haryana Journal of Agronomy. 4(1): 42-47.

Subbaiah, B. V. and Asija, G. L. 1956. Rapid procedure for estimation of available $\mathrm{N}$ in soils. Current Science. 25: 219-236.

Subbaiah, K., Helkaih, J., Ravikumar, V. and Rajagopal, 1982. Effect of combined application of organic and inorganic fertilizers on the yield and nitrogen uptake of MDV chilli. South Indian Horticulture. 30: 45-47. 
Tandon, H. Z. 1993. Methods of analysis of soils, Plant, Water and fertilizers.
Fertilizer development and consultation organization, New Delhi. 148.

\section{How to cite this article:}

Akhila, N., D. Anitha Kumari, M. Hanuman Nayak and Vijaya, D. 2019. Impact of Organic Manures and Biofertilizers on available NPK in Soil and Nutrient Composition Ofokra Fruit. Int.J.Curr.Microbiol.App.Sci. 8(05): 622-631. doi: https://doi.org/10.20546/ijcmas.2019.805.072 